\title{
Discussion on the Demand and Development Prospect of China's Three-dimensional Animation Talents
}

\author{
Yuexiu Wang \\ Dalian Neusoft University of Information \\ Dalian, China
}

\begin{abstract}
In recent years, as the number of graduates in animation has increased year by year, the employment pressure has also increased year by year. The employment situation of animation graduates has become less and less optimistic. It seems that there has been a big gap from the university campus to work. In order to solve this problem, we must first understand the talent demand of the animation industry, rethink the development of the animation major in colleges and the goal of talent cultivation, help students determine their professional development direction, and train students into the talents needed in the animation industry.
\end{abstract}

Keywords-animation major; employment; company; talent demand

\section{INTRODUCTION}

Since the rise of three-dimensional animation at the end of the last century, major international animation and movie companies have entered the field of 3D animation and began to explore three-dimensional animation technology. Threedimensional animation began to show its prominence in the international animation community, from the initial exploration to practical application, and then to the subsequent maturity of technology. In just two decades, three-dimensional animation has taken its place as an overlord of international animation. Many companies engaged in two-dimensional animation have changed their traditions and began to make three-dimensional animations, using three-dimensional animation as the company's main type of animation. For instance, Disney, the old American animation company, launched the last two-dimensional animated film "The Princess and the Frog" in 2009, and after that, the type of animation works has been fully converted into threedimensional animation. Another example is Japan's famous long series of animation "Astro-Boy" and " "Doraemon" have also launched a three-dimensional animation film; And in recent years, hit TV series animated cartoon "Bear infestation" and "Super Wings" are produced with three-dimensional technology. Thus, three-dimensional animation has become the most important type of animation in today's animation.

Since the 21 st century, the domestic animation industry has undergone earth-shaking changes. The country began to vigorously support the domestic animation industry, and several regions began to build animation industry parks. Large and small animation companies have grown up like mushrooms after spring rains and have spread across many cities in the country. The major media are racing to report that the promotion of $3 \mathrm{D}$ animation is fast and has a good momentum. There is a great employment need in the animation industry with high salary. For a while, animation has become a hot topic after everyone's meal. "Animators" have suddenly become the most fashionable and hottest jobs. Various types of three-dimensional animation training institutions have emerged one after another; colleges and universities have also set up animation professions in order to comply with social trends and developments; colleges that have already set up animation majors have also added relevant contents of the three-dimensional animation to animation professional courses. The importance of three-dimensional animation has gradually emerged.

In the context of the full-scale invasion of threedimensional animation, animation majors in colleges and universities began to expand their enrollments, resulting in a sharp increase in the number of students who applied for animation in the country. But, how many people in the selection of animation majors really love and have a certain understanding of animation? It is estimated that some students who choose animation majors have no knowledge of animation. Many students are blind followers when they choose to major in college. Most students who choose to major in animation are not simply because of their love, but because they or their parents think that this profession will develop well and make much money. And are the facts as smooth as they think? With the increasing number of graduates of animation majors, employment pressure has increased year by year, and the employment situation of animation majors has become increasingly less optimistic. The lack of animation talent originally promoted by the media does not appear. The employment situation of animation graduates is also not expected to be optimistic. The employment situation of most animation graduates is not satisfactory. Under the influence of the decrease in the employment rate, people who want to work in the animation profession are also decreasing year by year. In this situation, many students and parents of animation majors will not see their own problems, but they will feel that the media exaggerates their publicity, or they think that animation is a bad profession. 
The real situation is that the Chinese animation industry has just been revived. The employment gap is really big. The animation company does have a shortage of talents. However, the talents they need are definitely not just the person who just scratches his head, not a "can" but a "precision". What the company needs is talent that can stand alone. This requires our animation students not only to work diligently to learn animation-related knowledge, but also to understand the animation company's talent needs, to continuously improve themselves during four-year study process in university, and to purposefully train themselves to meet the needs of the industry's talent.

The talent standards of the industry demand are still to be determined by the talent demand standards of the first-line animation company. Through visits to a number of three- dimensional animation companies, we learned about related conditions of the animation company's division, job division and talent demand:

\section{THE DEPARTMENT OF THE THREE-DIMENSIONAL ANIMATION COMPANY AND THE DIVISION OF THE DEPARTMENT}

Three-dimensional animation companies generally divide departments and production teams according to the animation production process as shown in "Fig. 1" and the projects they produce. The production department is generally divided into a two-dimensional department and a three-dimensional department. The larger-scale company will be equipped with a planning department, an animation derivative development department, and a marketing department.

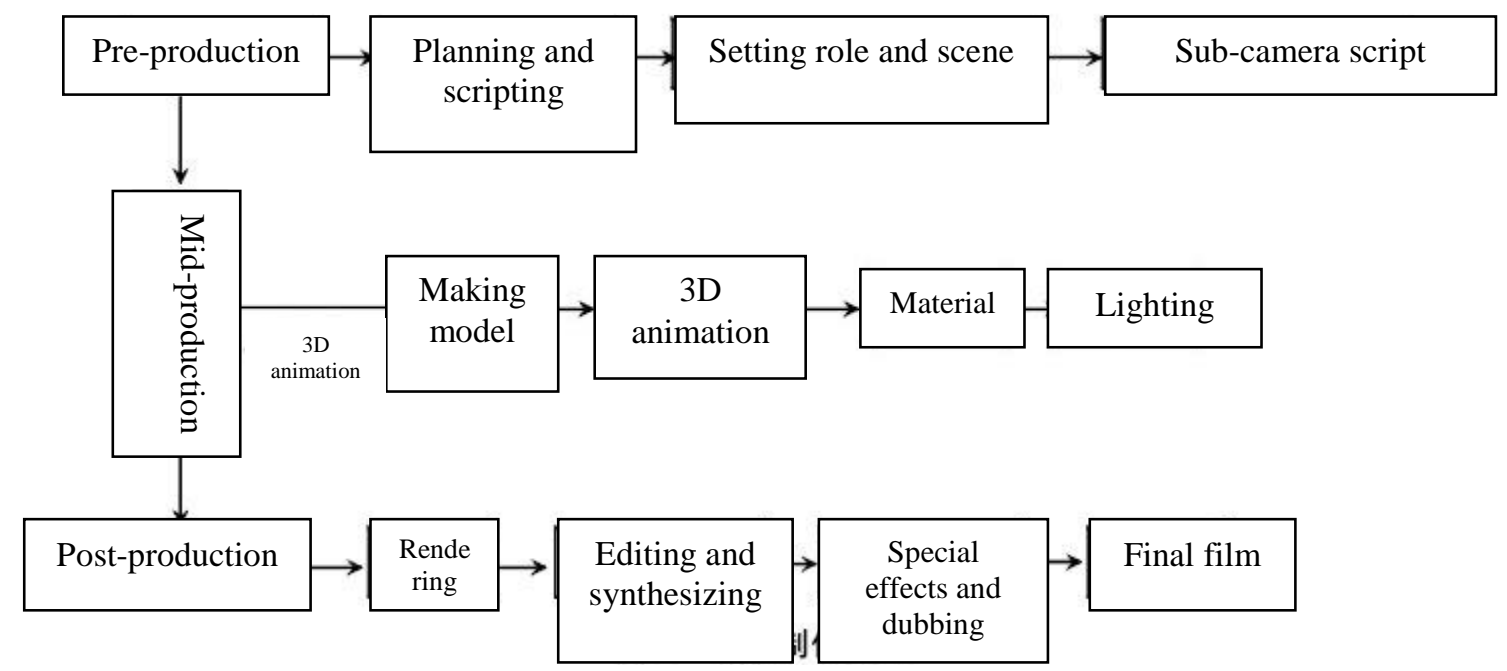

Fig. 1. Animation producing process

- Planning Department: People in this department are mainly engaged in the preliminary planning of animation projects, data collection and script writing. The animation companies with more projects are relatively employ more staffing. It may produce multiple animations at the same time. At this time, the members of the department need to be grouped according to the project. Each project team is responsible for the preliminary planning of a project. Project team members can assemble good ideas by brainstorm and eventually complete the creation of the script. The planned work in the early stage is closely related to creativity and literary quality. Therefore, the early planning needs are creative talents with broadmindedness, imaginativeness, understanding of the psychology of animated audiences, and high literacy.

- Two-dimensional department: People in this department are mainly engaged in the related work of the animation design. After getting the script, the first task is to complete the design of characters, scenes, and props; after that, the second task is to complete the design of the sub-camera. The designers of the twodimensional department must read the script and find inspiration from the script to complete the characters, scenes, props and sub-camera design that in accordance with the script. The work of the twodimensional department is closely related to the artistic skills and lens language. Therefore, the twodimensional department needs complex talents who are broad-minded, imaginative, understand the psychology of the animated audience, have strong artistic skills, and are skilled in the application of lens language.

- Three-dimensional department: People in this department are mainly engaged in mid-production of three-dimensional animation, it is the most important part of the entire three-dimensional animation production process. The three-dimensional animation mid-production is relatively complicated, so the department members must be grouped according to the three-dimensional animation production module, generally divided into model group, material lighting group, animation group, special effects group and rendering group. Each group has its own work task, and the work tasks of the groups are linked together in an orderly manner, and finally the cartoon production can be completed. After getting the design, the threedimensional department project manager and all group 
leaders need to meet to discuss the production methods, difficulties, staff division, and production cycle, etc., and produce a project production time schedule. The first is that the model group creates the characters, scenes, and prop models according to the 2D design; the well-made models are assigned to UV and then was given to the material lighting group and the animation group respectively. The material lighting group completes the model material map according to the design draft and the animation group binds the bones and adjusts the movements for models; then the models are sent to the material lighting group to adjust the texture mapping and set the lights; the shots that require special effects are sent to the special effect group, and the rendering group finally outputs the products. The work of the three-dimensional department is related to the observation power, artistic sense, and proficiency in software operation. Therefore, the three-dimensional department needs complex talents who are open-minded, imaginative, aware of the psychology of the animated audience, and have a strong sense of art and master threedimensional animation software applications.

- The Latter Part Department: people in this department are mainly engaged in late special effects add processing, dubbing, editing, synthesis, color correction and output. The work of the latter stage is related to the sense of music, the sense of art, the sense of time, and the proficiency of post-software operation. Therefore, the latter department needs to be broadminded, imaginative, aware of the psychology of the animated audience, strong sense of art, strong sense of time, and mastery in late-model software.

- Animation Derivatives Development Department: people in this department are mainly responsible for the shaping of the animated character's threedimensional modeling and the design and production of animation derivatives. As an ancillary product of an animation, an animation derivative product is similar to animation. Animated fans will be attracted and purchased when seeing that the animation's derivative products, creating more value for the animation company; at the same time, good animation derivative products will also increase the popularity of the animation, adding more fans for the animation, and many animation fans may know the animation because of an animation derivative product. The successful marketing of derivative product design by Disney Animation in the United States has earned numerous profits for Disney, which is a very successful case. The work of the Animation Derivatives Development Department is closely related to creativity, styling abilities, and sculpting skills. Therefore, the Department of Animation Derivatives Development needs practical talent with broad thinking, imaginative skills, strong styling abilities, and high sculpting skills.

- Marketing Department: people in this department are mainly responsible for animation promotion, marketing and market research. Marketing experts in the marketing department will fully package the produced animations and sell them as best they can. TVs, theaters, mobile devices, domestic and foreign animation competitions are all platforms that they can use.

The quality of production at each stage is checked by group leader, project manager and animation director. In the production process, it is necessary to communicate with the animated director, the original painter, and the sub-camera designer to minimize the difference between the film and the initial settings, and to ensure the perfect realization of the original cartoon and original painting effects.

Through the knowledge of the department and group division of three-dimensional animation companies, students are made aware of the production process of three-dimensional animation, the relationship between module division and the division of three-dimensional animation company departments, and determine the primary and secondary learning modules, clarifying the learning ideas and doing a good job in professional study planning.

\section{THE THREE-DIMENSIONAL ANIMATION COMPANY'S JOB DIVISION AND JOB RESPONSIBILITIES}

\section{A. Job Division and Job Responsibilities of Planning Department}

- Animated director: he is mainly responsible for creative animation and planning and design of animation outline. He should have a certain degree of artistic accomplishment and literary accomplishment and the ability to "edit" and "guide" an animation.

- Scriptwriter: he charges script writing.

\section{B. Job Division and Job Responsibilities of Two-Dimensional Department}

- Original painting designer: According to the script content to complete design of the role, props, scene original.

- Sub-camera designer: According to the script content and the completed role, props, scene original design to complete the shooting of the sub-camera.

\section{Job Division and Job Responsibilities of the Three- Dimensional Department}

- Modeler: According to the characters, props, scenes original design to make model with three-dimensional animation software. The model is the first link, because other parts can't be performed without model. Generally, in a company with a small scale, all production personnel must jointly complete the production of the model. The model group with a strong styling ability is responsible for the production of major models such as characters. Other production personnel are divided tasks by the ability to make models, and create relatively simple models such as props and scenes. 
- Material Master: The modeler assigns the model of characters, scenes, and props to the material master. The material master will make model texture maps based on the characters, props, and scene original design.

- Animator: The material master hands over the model of the material texture to the animator. The animator worked on character binding, character animation, and lens animation based on the sub-camera design.

- $\quad$ Lighting engineer: the animator produces a good lens file to the lighting engineer. The lighting engineer will set the overall lighting according to the scene design and the sub-camera design.

- $\quad$ VFX Artist: If there are special effects, VFX artist will perform special effects test production based on the lens file.

- Renderer: The final shot file is given to the renderer, and batch rendering is performed according to the shot.

\section{Job Division and Job Responsibilities of the Latter Part} Development

- Post-production personnel: Rendered files are handed to post-production personal for synthesis, editing, dubbing, subtitles, post-production, etc., and finally output a complete film.

\section{E. Job Division and Job Responsibilities of the Animation Derivatives Department}

- Animation Derivative Designer: Responsible for the design of animation derivatives. Derive the design of derivatives based on the animated animation, write design plans and draw a graphic design.

- Animation Derivatives Sculptor: Perform physical sculpture based on animated derivative design.

Through the knowledge of job division and job responsibilities of the three-dimensional animation company, students can understand the job requirements of the threedimensional animation company and determine their own research goals and directions.

\section{THE THREE-DIMENSIONAL ANIMATION COMPANY'S REQUIREMENTS FOR THREE-DIMENSIONAL ANIMATION PRODUCTION PERSONNEL}

- Generally, animation company requires threedimensional animation production personnel to be familiar with the entire animation production process and understand the production content of each module, so as to better match the production of animations with other modules.

- Animation companies require three-dimensional animation production staff to select a module that they are best at as the main work direction based on the familiarity with the animation production process. It is better to choose a second module as the secondary work direction, so that the future development will be better. It should be noted that animation companies do not require three-dimensional animation production staff to be proficient in everything. After all, people's energy is limited and it is unrealistic to be proficient in everything. There are many reasons: firstly, the threedimensional production process divides multiple modules; secondly, the content of each module is very complicated; thirdly, people's time and experience are limited. Therefore, a three-dimensional animation production staff cannot be very proficient in everything. If there is a person who is in charge of everything, then he is certainly not perfect in anything.

- Animation companies require three-dimensional animation producers to constantly pursue progress. The animation company regularly tests the capabilities of its employees and grades the employee's job capabilities. Taking the position of the modeler as an example, it is divided into a first-level modeler, a second-level modeler, and a third-level modeler. The higher the level of the ability of the modeler, the higher the difficulty of the assigned model task is and the higher the salary.

By recognizing the requirements of the three-dimensional animation company's production staff, students can be made aware of the effects that three-dimensional animation learning needs to achieve, strictly require themselves, and constantly break through to achieve higher standards.

\section{CONCLUSION}

Through the investigation and analysis of the above points, we can understand some of the needs of China's threedimensional animation talent needs. Three-dimensional animation is a very young and promising type of animation. Its development prospects are infinitely wide. More threedimensional animation talents are needed to involve in the animation industry and college animation. If animation students want to be a useful animation talent, in addition to mastering professional knowledge and skills, they must also have a certain understanding of the talent needs of the entire industry. As the "Book of Rites, The Doctrine of the Mean" stated, "Everything is foretold and is not to be abandoned." No matter what you do, there will be success with preparation, and failure without preparation. For better development in the future, students need to start preparations as early as possible, but they should not be blindly prepared. They must prepare purposefully and systematically so that they will eventually succeed. The students of the animation major must first develop professional basic skills in the first two years of the university. When they are in junior year, they must study the talent demand of the animation industry, determine their own development direction, and purposely train themselves to meet the needs of the industry. It has not only contributed to the development of the Chinese animation industry, but also achieved their value and truly achieved a win-win result. 


\section{REFERENCES}

[1] Status Quo and Optimization of Talent Cultivation in Animation Industry in China [J].Geng Rui. China Radio \& TV Academic Journal.2017(09). 中国动画产业人才培养现状及优化路径[J].耿荵.中 国广播电视学刊.2017(09)

[2] The Training of Talents in Animation Teaching in Colleges and Universities Should be effectively matched with the Demand for the Development of Animation Industry. [J].Yi Qinyin. Home Drama.2017(18) . 高校动画教学人才培养应与动画产业发展需求有 效对接 $[\mathrm{J}]$.易芹因.戏剧之家.2017(18)

[3] Application of Project Teaching Method in Linear Algebra Teaching[J].Liu Yanyan, Wang Jianguo. Education and Vacation.2016(04). 项目教学法在线性代数课程教学中的应用[J].刘 艳艳, 王建国.教育与职业.2016(04)

[4] Discussion on the Development of Three-dimensional Animation in China and the Training of Talents[J]. Zhang Ting. Modern Enterprise Education.2012(17). 国内三维动画的发展与人才培养的探讨 [J].张霆. 现代企业教育.2012(17)

[5] Study on the Reform of Three-dimensional Animation Personnel Training Based on Job Ability Demand[J]. Li Mingchao, Liu Liping. Art Education Research.2012(22). 以岗位能力需求为导向的三维动画 人才培养改革研究[J]. 李铭超, 刘丽萍.美术教育研究.2012(22) 